\title{
Pleomorphic Adenoma of the Lower Lip: A Case and Review of the Japanese Literature
}

\author{
by \\ Hirotsugu YAMAMOTO, Masahiko FUKUMOTO, Takashi MATSUMOTO,* \\ Miho KOHNO,* Shigeo OHTAKE, Kazumasa OZAWA** \\ and Kenji KANEKO** \\ (Received 15 July 1985)

\section{Introduction}

Pleomorphic adenoma is the most common tumor of the salivary glands and mainly occurs in the major salivary glands, the parotid gland in particular ${ }^{[1,2]}$, and it is relatively rare in the minor salivary glands. Among the latter the palate is the most common site for pleomorphic adenomas ${ }^{[3,4]}$, and pleomorphic adenomas in the lip are rare, particularly in the lower $\operatorname{lip}^{[5,6]}$.

We encountered a case of pleomorphic adenoma in the lower lip and reviewed the Japanese literature on labial pleomorphic adenomas.

\section{Report of Case}

On November 7, 1980, a 53-year-old female visited our University Dental Hospital at Matsudo with the chief complaint of swelling in the lower lip. She noticed a mass 6 months ago, but she did not seek medical care because there was no pain. However, the mass gradually grew bigger and she went to a private dentist who referred her to our hospital. On her first visit, a soy-bean sized tumor was observed in the lower right lip on oral examination (Fig. 1). The tumor was hard and elastic and the overlying mucosa appeared to be quite movable against the underlying tissue. Her general condition was not remarkable. Her past and family histories showed nothing unusual. The clinical diagnosis was adenoma. The tumor was excised under local anesthesia. She had no recurrence for 4 years after that.

Grossly, the excised material was an oval and slightly hard tumor measuring 1.0 by 0.8 by $0.6 \mathrm{~cm}$. On the cut surface, it appeared solid and grayish-white with a thin capsule (Fig. 2).

Microscopically, the tumor consisted of the proliferation of polyhedral or cuboidal epithelial cells with oval or vesticular nuclei (Figs. 3 and 4). These cells formed small glands or cystic spaces containing PAS or alcian blue positive materials and revealed solid alveoli or trabeculae in some areas (Fig. 4). A few squamous metaplasia of the epithelial cells were also seen. The stroma contained about $30 \%$ stromal content, consisting of alcian blue positive myxoid tissues

山本浩嗣, 福本雅彦, 松本 敬, ${ }^{*}$ 河野美保, ${ }^{*}$ 大竹繁雄, 小沢和正 ${ }^{* *}$, 金子賢司 ${ }^{* *}$ : Departments of Clinical Pathology, *Central Laboratory and ** Oral Surgery, Nihon University School of Dentistry at Matsudo. 


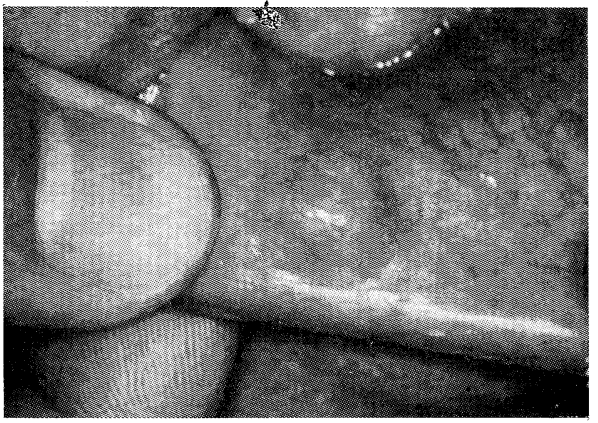

Fig. 1 A soy-bean sized tumor is observed in the lower right lip on the first visit.

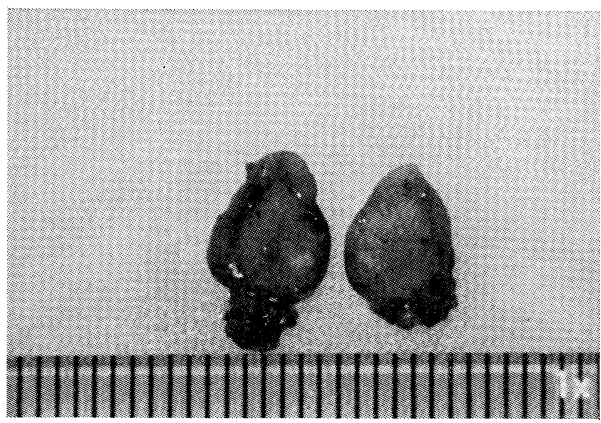

Fig. 2 The excised material is an oval and slightly hard tumor that is grayishwhite on the cut surface.

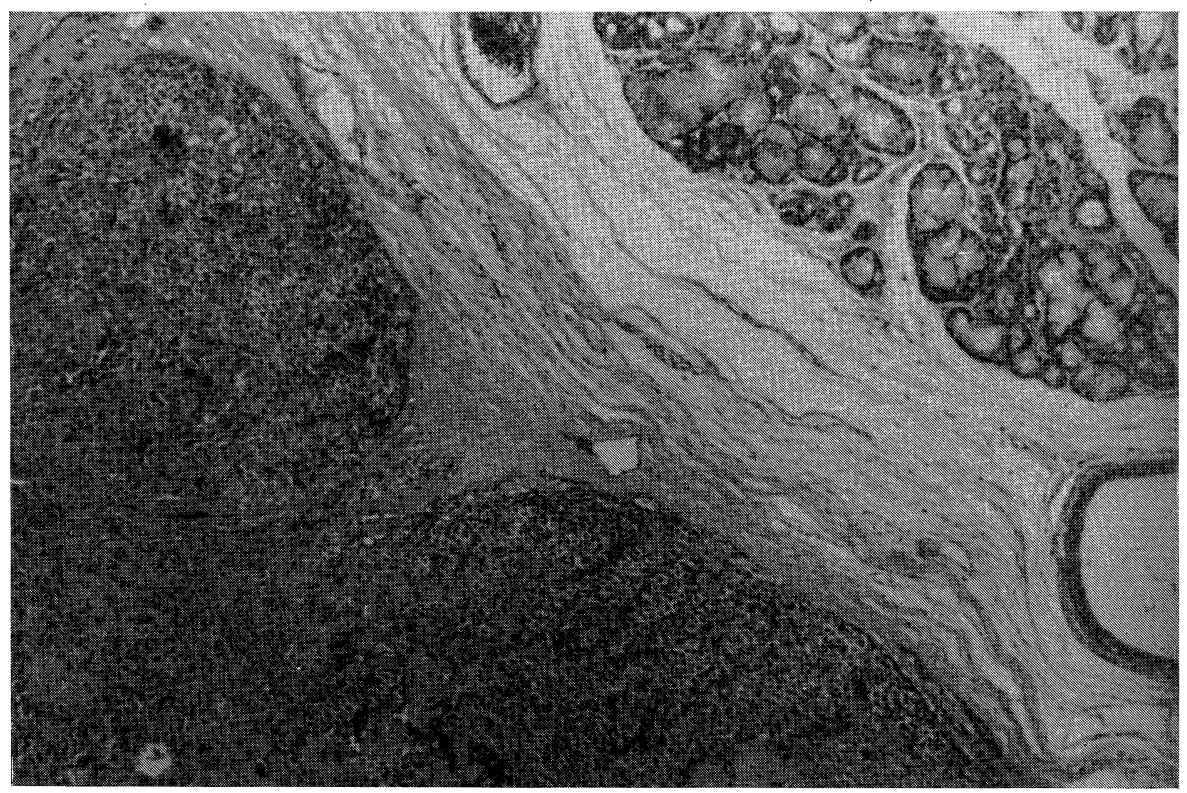

Fig. 3 .Histopathology of the tumor showing epithelial proliferations surrounded by fibrous connective tissue, including normal labial glands. (Hematoxylin and eosin, $\times 40$ )

associated with fibrous and hyalinized connective tissues (Fig. 4). The tumor was surrounded by thin fibrous connective tissue with normal labial glands (Fig. 3). The histopathology of the tumor was classified as pleomorphic adenoma corresponding to subtype I using the subclassification of pleomorphic adenomas by SEIFERT et al ${ }^{[2]}$. 


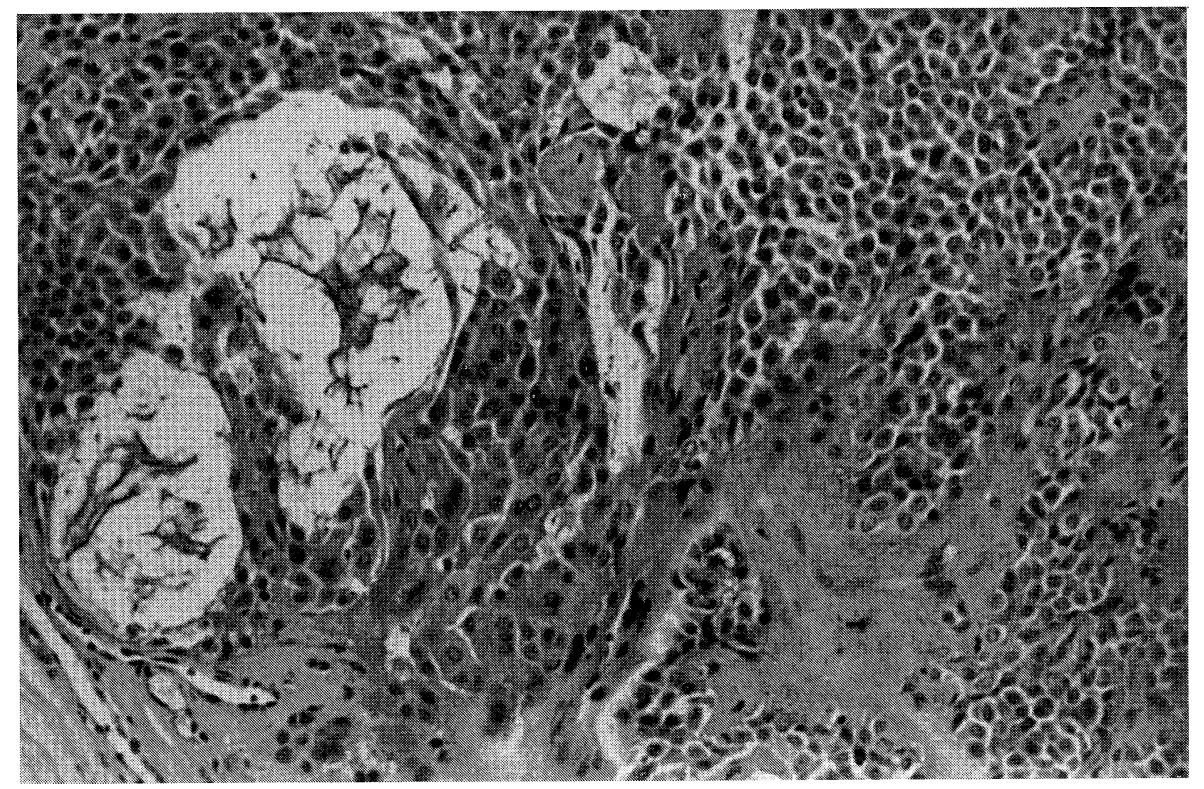

Fig. 4. The tumor cells are composed of polyhedral and cuboidal epithelial cells which occasionally form small glands and cystic spaces. The stroma reveals myxomatous tissues. (Hematoxylin and eosin, $\times 100$ )

\section{Discussion}

The occurrence rate of pleomorphic adenomas is the highest among salivary gland tumors. According to RAUCH et al. ${ }^{[7]}$, they are located $92.5 \%$ of the time in the major salivary glands, $6.5 \%$ in the minor salivary glands and in the others, 1 $\%$. Among the minor salivary glands, the palatal gland is the most affected site, $67.5 \%$, then the lip $10 \%$, cheek $5 \%$, tongue $2.5 \%$ and others $15 \%{ }^{[4]}$. Thus the occurrence of minor salivary and labial gland pleomorphic adenomas is generally rare. The occurrence rate of labial pleomorphic adenomas in the minor salivary glands ranged from 2.3 to $30.4 \%^{[5,8-12]}$. There have been 33 cases of labial pleomorphic adenoma reported in Japanese literature. The Japanese cases of labial pleomorphic adenomas, including our own case, are shown in Table 1. As for the location, the upper lip was more affected than the lower lip (29 upper and 4 lower). BERNIER ${ }^{[20]}$ and KROLLS et al. ${ }^{[5]}$ stated the same tendency, ranging from 85 to $92 \%$. The occurrence of lower lip pleomorphic adenomas is rare, as mentioned above. For the reason for predominance of the upper lip, BERNIER ${ }^{[20]}$ gave the explanation that the developmental process was more complex in the upper than in the lower lip and resulted in an aberration of embryonal epithelium. In addition, Krolls et al. ${ }^{[5]}$ suspected that the lower lip, being exposed to trauma such as biting and absorption, induces inflammatory changes and destroys tumor potential cells. Twelve cases were seen on the left and right sides, respectively, and 5 in the median. BERNIER ${ }^{[20]}$ reported a slight predominance of the left side. The ratio 


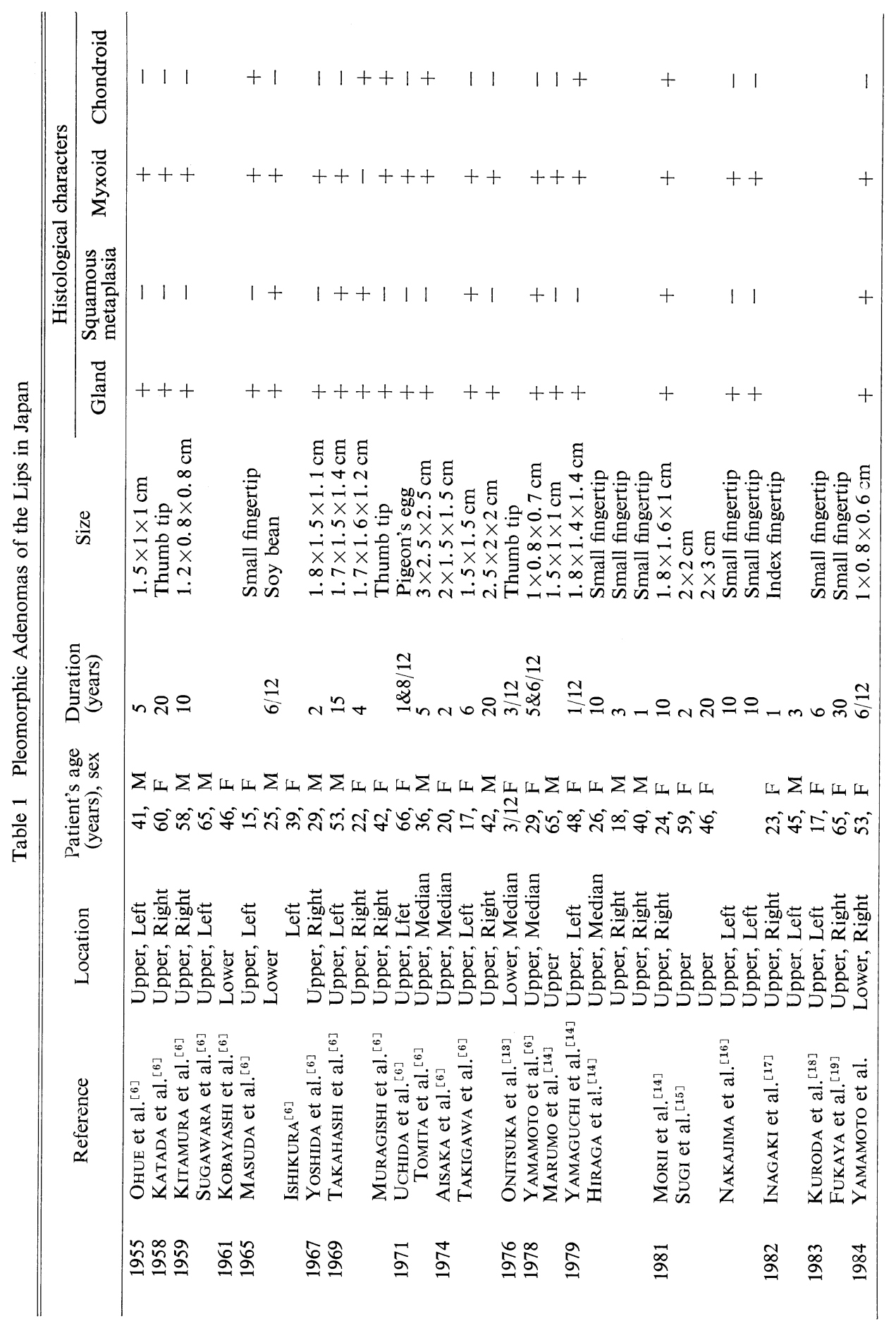


Table 2 Differential Points between Pleomorphic Adenomas and Mixed Tumors

\begin{tabular}{lll}
\hline \hline & Pleomorphic adenomas & Mixed tumors of the skin \\
\hline $\begin{array}{l}\text { Clinical Findings } \\
\text { Location }\end{array}$ & Submucosa & Subcutaneous \\
Age & $20-40$ decades & $30-50$ decades \\
Sex & Male $\leqq$ Female & Male $>$ Female \\
Duration & 7.2 years & 7 years \\
Size & $\phi 1-2 \mathrm{~cm}$ & $\phi 1-2 \mathrm{~cm}$ \\
\hline Histological Findings & & \\
Myxoid area & Many & Relatively few \\
Modification of nests & Many & Few \\
Glandular wall & Mainly double & Eccrine: single \\
Solid area & Common & Apocrine; more than double \\
Squamous metaplasia & Few & Few \\
\hline
\end{tabular}

on males to females was 1:1.7 (12 males and 20 females). However, males were more affected in other countries ${ }^{[5,20]}$. The average age of Japanese labial pleomorphic adenomas was 38.6 years, ranging from 3 months to 66 years. Duration of the illness was from 3 months to 30 years. The average was 7.2 years. The size of the tumor was, in general, small with an average diameter of $18 \mathrm{~mm}$.

SEIFERT et al. ${ }^{[2]}$ classified pleomorphic adenomas into four types; I, $\mathrm{II}_{\mathrm{a}-\mathrm{e}}$, III and IV. In 20 cases with detailed histologic descriptions, tumors associated with the myxoid area corresponding to subtype $\mathrm{I}_{\text {or }} \mathrm{II}_{\mathrm{a}}$ by SEIFERT's subclassification were more often in labial pleomorphic adenomas. Chondroid stroma was not seen as often in the labial pleomorphic adenomas as compared with that of pleomorphic adenomas in major salivary glands according to FOOTE et al. ${ }^{[21]}$ The structure of the labial gland is similar to other salivary glands except for the presence of the short duct ${ }^{[22]}$. The reason why chondroid stromata occur less in labial pleomorphic adenomas is not very clear.

At the lip, there were not only pleomorphic adenomas in the salivary gland but also mixed tumors in the sweat glands ${ }^{[6,23-25]}$. It is necessary to differentiate their origin from that of salivary or sweat glands because of their close anatomic relationship at the lip. The differential points between pleomorphic adenomas in the salivary gland and mixed tumors of the sweat gland are listed in Table 2 based on the reported literature ${ }^{[6,23-25]}$. In differential clinical points of view, pleomorphic adenomas are located in the submucosa of the oral cavity, but mixed tumors of the skin are subcutaneous. The patient's age is a little higher in mixed tumors than in pleomorphic adenomas. Histopathologically, the myxoid area and modification of tumor nests are more often met in pleomorphic adenomas. Basically, the glands of pleomorphic adenomas are formed by double layers. Squamous metaplasia is more frequent in mixed tumors.

\section{Summary}

Pleomorphic adenomas of the lower lip are rare. We described a case of a pleomorphic adenoma in the lower lip of a 53-year-old female. The cases reported 
in Japanese literature were reviewed. The differential points between labial pleomorphic adenomas and mixed tumors of the skin were also discussed.

\section{Refetences}

[1] Thackray, A.C. and Lucas, R.B.: Tumors of the major salivary gland (1st ed.), Washington DC., AFIP, 1974.

[2] Seifert, G., Langrock, I. and Donath, K.: Pathomorpnoıogisch Subklassifikation der pleomorphen Speicheldrüsenadenome, $H N O, 24,415,1976$.

[3] Seifert, G., Rieb, H. and Donath, K.: Klassifikation der Tumoren der kleinen Speicheldrüsen, Laryng Rhinol., 59, 379, 1980.

[4] Chaudhry, A.P., Vicker, R.A. and Gorlin, R.J.: Intraoral minor salivary gland tumors: An analysis of 1414 cases, Oral Surg., 14, 1194, 1961.

[5] Krolls, S.O. and Hicks, J.: Mixed tumors of the lower lip, Oral Surg., 35, 212, 1973.

[6] Yамамото, H., Tagaki, M., Izumi, H. et al.: A case of pleomorphic adenoma occurred in the upper lip, JJSS., 27, 83, 1978. (in Japanese)

[7] Rauch, S. and Masshoff, W.: Die talgdrüsenähnlichen Sialome, Frankfr. Z. Path., 69, 513, 1959.

[8] Bergman, F.: Tumors of the minor salivary glands, Cancer, 22, 538, 1969.

[9] Kodama, M.: Clinicopathological studies of salivary gland tumors, Nihon Univ. Dent. J., 43, 307, 1969. (in Japanese)

[10] Crocker, D.J., Cavalaris, C.J. and Finch, R.: Intraoral minor salivary gland tumors, Oral Surg., 29, 60, 1970.

[11] Soskolne, A., Ben-Amar, A. and Ulmansky, M.: Minor salivary gland tumors: A survey of 64 cases, J. Oral Surg., 31, 528, 1973.

[12] Ishikawa, G., Akiyoshi, M., Ishiki, T. et al.: Oral Pathology II (5th ed.), Kyoto, Nagamatsu Shoten, 1982. (in Japanese)

[13] Onitsuka, K., Iguchi, T. and IKeJiri, S.: Pleomorphic adenoma of the lower lip in a 3-monthold baby: Report of a case, Jpn. J. Oral Surg., 22, 965, 1976. (in Japanese)

[14] Morit, E., Toyoshima, H. and TAKada, K. et al.: Two cases of pleomorphic adenoma occurring in minor salivary glands, Tohoku Dent. J., 8, 72, 1981. (in Japanese)

[15] Sugi, Y., Ito, N., NiHeI, T. et al.: Benign pleomorphic adenoma occurring in minor salivary glands, Dent. J. Iwate Med. Univ., 1, 83, 1981. (in Japanese)

[16] Nakajima, T., Yamamoto, M., Miyata, K. et al.: Pleomorphic adenoma of the lip, JJSS, 30, 581, 1981. (in Japanese)

[17] Inagaki, T., Tanabe, A., Nishio, J. et al.: Pleomorphic adenoma of the upper lip: Report of tow cases, Jpn. J. Oral Surg., 28, 963, 1982. (in Japanese)

[18] Kuroda, F., Honda, M., Arima, M. et a1.: Pleomorphic adenomas of the upper lip, cheek, and floor of the mouth: Report of three cases, Nihon Univ. Dent. J., 57, 192, 1983. (in Japannese)

[19] Fukaya, S., Takigawa, N. and Tomita, T.: A pleomorphic adenoma occurring in the upper lip, Jpn. J. Oral. Surg., 29, 1161, 1983. (in Japanese)

[20] Bernier, J.L.: Mixed tumors of the lip, J. Oral Surg., 4, 193, 1946.

[21] Foote, F.W. and Frazell, E.L.: Tumors of the major salivary glands, Cancer, 65, 1065, 1953.

[22] Bhaskar, S.N.: Orban's oral histology (9th ed.), St Louis, The C.V. Mosby Company, 1980.

[23] Stout, A.P. and Gorman, J.G.: Mixed tumors of skin of the salivary gland type, Cancer, 12, 537, 1959.

[24] Masuda, T. and Ikeda, S.: The relation between so-called mixed tumors of the skin of salivary gland type, Jpn. J. Dermatol., 75, 1, 1965. (in Japanese)

[25] Lever, W.F. and Schaumber-Lever, G.: Histopathology of the skin (5th ed.), Philadelphia, J.B. Lippincott Company, 1975. 